\title{
The Suitability of Legumes for Rangeland Interseeding and as Grasshopper Food Plants
}

\author{
GEORGE B. HEWITT, A.C. WILTON, AND R.J. LORENZ
}

\begin{abstract}
Fifteen legume varieties (selections representing 7 species) which have some potential for reseeding into rangeland were evaluated in the laboratory and in the field as to their suitability as food plants for several species of rangeland grasshoppers. Varieties of alfalfa, trefoil, and cicer milkvetch were less preferred than varieties of sanfoin, sweetclover, hairy vetch, and crown vetch. Three plant varieties, alfalfa (Mandan composite-1), birdsfoot trefoil (Cree), and cicer milkvetch (Mandan Composite-2) were the least preferred of the varieties tested based on the rate of grasshopper development and weight of adults reared on the test plants, the time spent feeding during a 30-min period, and plant mortality and $\%$ leaf reduction in a field test. Alfalia appeared to have the greatest potential for reseeding on arid rangeland sites. Nonpreference is the main resistance factor that should be used when screening rangeland plants for grasshopper feeding preferences.
\end{abstract}

The seeding of legumes into rangeland has the potential to become a useful practice for range improvement as suitable species and varieties become available, and as interseeding technology develops. The merits of the presence of the legume include increased forage production and improved animal performance (Heinrichs 1963, Wilton et al. 1978, and Lorenz 1982 et al.). Millions of acres of rangeland in the western United States and in other countries could be improved by the successful introduction of legumes to the existing grassland (Kneebone 1959, Atkins 1962, Bleak et al. 1965, Rumbaugh et al. 1965). However, only a few species have the necessary adaptive requirements to persist in an arid enviroment in competition with grass and forb species under grazing conditions.

A potential range legume should have many if not all of the following characteristics: (1) drought resistance, (2) winter hardiness, (3) disease resistance, (4) insect resistance, (5) persistence (survive frequent removal of top growth and trampling by livestock), (6) aggressiveness (sufficient vigor for establishment and competition with grasses and other vegetation), (7) reproduce voluntarily by seed and/or have a spreading root system, (8) non-bloating, (9) adaptation to wide range of soil types, (10) low preference by rodents, (11) spring growth pattern compatible with other species in the stand.

Several legume species with some of the above characteristics have been tested on rangeland; these include alfalfa, Medicago sativa and $M$. falcata; sainfoin, Onobrychis viciifolia; sweetclover, Melilotus officinalis; cicer milkvetch, Astragalus cicer; and birdsfoot trefoil, Lotus corniculatus. Birdsfoot trefoil does not cause bloat and is adapted to low phosphorus soils, acid soils, and soils with poor internal drainage (Henson and Schoth 1962, Vogel and Berg 1968, Seaney and Henson 1970, and Cooper et al. 1971). However, this plant is non-aggressive, has low seedling vigor, and

\footnotetext{
Authors are at the Rangeland Insect Laboratory, Agr. Res., U.S. Dep. Agr., Agr. Res. Serv., Bozeman, Mont. 59717 , and Northern Great Plains Research Laboratory, U.S. Dep. Agr., Agr. Kes. Serv., Mandan, N. Dak. 58554.

Manuscript received April 6, 1981.
}

is slow to establish (Seaney and Henson 1970, Cooper et al. 1971). Cicer milkvetch does not cause bloat, remains green in the fall, recovers rapidly from grazing, has a creeping rhizome system which could reduce damage by pocket gophers, and is moderately salt tolerant and drought resistant (Johnston et al. 1971, Stroh et al. 1972, and Johnston et al. 1975). The disadvantages of cicer milkvetch are that it begins growth later in the spring than alfalfa and has slow seedling growth (Johnston et al. 1971, Smoliak et al. 1972, Johnston et al. 1975). Alfalfa appears to show the greatest promise for use on rangelands since it is very aggressive, hardy, persistent, drought resistant, withstands grazing, and creeping root va rieties are available (Kilcher and Heinrichs 1966, Heinrichs 1971 ab, Rauzi et al. 1974, Townsend et al. 1975, Cooper 1977, Rumbaugh and Pedersen 1979). However, alfalfa does cause bloat. Several alfalfa varieties have been released for use in the range environment, (Rumbaugh et al. 1965, Kilcher and Heinrichs 1968, Heinrichs 1971 a, and Stroh et al. 1972) but successful establishment in grasslands continues to be a problem. Both sainfoin and sweetclover are difficult to establish. The sweetclover weevil can cause seedling failures with sweetclover (Gomm 1964, Craig 1978) and although sainfoin has a number of insect pests, they apparently do not affect stand establishment (Hewitt and Burleson 1976). All of these species have some insect problems that could affect seedling establishment and survival. How many insect pests of irrigated forages would increase and become injurious to rangeland legume plantings is unknown. It does appear that grasshoppers, which occur in varying densities on western rangeland, would be one of the more important economic insect groups.

Six common grasshoppers (Melanoplus sanguinipes, $M$. bivittatus, $M$. femurrubrum, $M$. differentialis, $M$. packardii, and $M$. gladstni) are known to be general feeders that prefer forbs. At least one of these species is generally involved whenever legume plants are damaged or destroyed by grasshoppers. Of the many reasons reported for seedling failure or reduction in yield (drought, gophers, rabbits, competitive vegetation, etc.) grasshoppers are among the most common (Brown 1956, Bleak et al. 1965, and Rumbaugh 1965).

This paper reports on the suitability of 15 legume varieties and species selections as food for some of the more common grasshopper species that are pests of crops and rangeland forbs. Both laboratory and field tests were used to evaluate the plant material

\section{Methods and Materials}

\section{Laboratory Tests}

Fifteen legume selections (Table 1) were screened in the laboratory for grasshopper feeding preference and antibiosis by using 4 different types of criteria:

1. Grasshopper developmental time (days) from hatching to the adult stage when reared on the test plants.

2. Number of grasshoppers reaching adult stage.

3. Dry weight of adults reared on the test plants.

4. Total time spent feeding on the plants. 

Table 1. Survival, growth rate, and adult weight of Melanoplus gladstoni and $M$. sanguinipes reared in the laboratory on 15 legume selections, Bozeman,
Mont. 1980.

\begin{tabular}{|c|c|c|c|c|c|c|c|}
\hline \multirow[b]{2}{*}{ Plant species } & \multirow[b]{2}{*}{ Selection } & \multicolumn{2}{|c|}{$\begin{array}{l}\text { No. individuals } \\
\text { reaching adult stage }\end{array}$} & \multicolumn{2}{|c|}{$\begin{array}{l}\text { Avg. time to become } \\
\text { adults (days) }\end{array}$} & \multicolumn{2}{|c|}{$\begin{array}{c}\text { Avg. dry wt (mg) of } \\
\text { adults }\end{array}$} \\
\hline & & $\begin{array}{c}\boldsymbol{M} \\
\text { gladstoni } \\
\end{array}$ & $\begin{array}{c}M . \\
\text { sanguinipes }\end{array}$ & $\begin{array}{c}M . \\
\text { gladstoni }\end{array}$ & $\begin{array}{c}M . \\
\text { sanguinipes }\end{array}$ & $\begin{array}{c}M . \\
\text { gladstoni }\end{array}$ & $\begin{array}{c}M . \\
\text { sanguinipes }\end{array}$ \\
\hline \multicolumn{6}{|l|}{ Alfalfa } & & \\
\hline Medicago falcata & Composite-1 & 5 & 3 & 48 & 35 & 193 & - \\
\hline \multirow[t]{3}{*}{ M. sativa } & Mal 40 & 2 & 6 & 44 & 33 & 220 & 137 \\
\hline & Ladak 65 & 6 & 0 & 48 & - & 234 & - \\
\hline & Orenburg & 8 & 0 & 47 & - & 228 & - \\
\hline \multirow{3}{*}{$\begin{array}{l}\text { Birdsfoot trefoil } \\
\text { Lotus comiculatus }\end{array}$} & & & & & & & \\
\hline & Mal 20 & 3 & 0 & $\begin{array}{l}50 \\
47\end{array}$ & - & 213 & - \\
\hline & $\begin{array}{l}\text { ML } 1974 \\
\text { Cree }\end{array}$ & $\begin{array}{l}4 \\
6\end{array}$ & $\begin{array}{l}0 \\
0\end{array}$ & $\begin{array}{l}47 \\
50\end{array}$ & $\overline{-}$ & 236 & - \\
\hline \multirow{2}{*}{\multicolumn{8}{|c|}{$\begin{array}{l}\text { Cicer milkvetch } \\
\text { Astragalus cicer }\end{array}$}} \\
\hline Astragalus cicer & Mandan & & & & & & \\
\hline \multicolumn{8}{|l|}{ Crown vetch } \\
\hline $\begin{array}{l}\text { Cornilla varia } \\
\text {. }\end{array}$ & ML. 1978 & 7 & 7 & 43 & 32 & 297 & 122 \\
\hline \multicolumn{8}{|l|}{ Hairy vetch } \\
\hline \multicolumn{8}{|l|}{$\begin{array}{l}\text { Vicia villosa } \\
\text { Sainfoin }\end{array}$} \\
\hline \multirow[t]{3}{*}{ Onobrychis viciifolia } & Eski & 7 & 2 & 42 & 32 & 267 & 107 \\
\hline & Melrose & 11 & 5 & 41 & 33 & 327 & 121 \\
\hline & Remont & 11 & 8 & 42 & 30 & 326 & 127 \\
\hline \multirow{2}{*}{$\begin{array}{l}\text { Sweetclover } \\
\text { Melilotus officinalis }\end{array}$} & Mal 47 & 11 & 8 & 44 & 31 & 278 & 153 \\
\hline & ML 2177 & 2 & 8 & 42 & 29 & 305 & 121 \\
\hline
\end{tabular}

${ }^{2}$ Average $d r y$ wt is the average wt of $q$ and average wt of $\sigma$ added together.

These criteria were used in assessing plant suitability using two grasshopper species, $M$. gladstoni and $M$. sanguinipes. Grasshopper species used in the tests were selected because they were available and because they were general feeders preferring forbs. M. gladstoni was reared singly in small plastic tubes (dia. $30 \mathrm{~mm} \times$ $105 \mathrm{~mm}$ long); 15 per plant selection. M. sanguinipes were reared in plastic tubes (dia. $46 \mathrm{~mm} \times 196 \mathrm{~mm}$ long); 15 per plant species and 5 grasshoppers per tube. Rearing was carried out in a greenhouse with a photo-period of 12 hours of darkness and 12 hours of light and a temperature averaging $27^{\circ} \mathrm{C}$ during the 12 hours of light and $24^{\circ} \mathrm{C}$ during the 12 hours of darkness. Each group of 15 grasshoppers was fed daily with the assigned plant selection and a small amount of dry wheat bran. The above and two additional species, $M$. packardii and $M$. femurrubrum were used in feeding tests to determine the average feeding time on each of the 15 legume selections. Adults were caged on potted plants in the laboratory and the time spent feeding during a $1 / 2$ hour period was recorded. The grasshoppers were without food for 18 hours prior to testing. Five grasshoppers, one to a cage, were tested at one time and the average feeding time of the 5 grasshoppers was used to assess the food preference for that particular plant selection.

Legume seeds were planted the first week of January 1980, and the rearing tests with lst instar grasshoppers were started on February 25,1980 . The timed feeding tests were conducted during the last of March and the first part of April 1980.

\section{Field Tests}

All 15 legume selections were interseeded into an $8-\mathrm{cm}$ scalped furrow in an existing stand of crested wheatgrass (Agropyron desertorum) and bromegrass (Bromus inermis) on May 6, 1980, at Mandan, North Dakota. The experimental design was a randomized block with 4 replications. Rows in each block were $7.6 \mathrm{~m}$ in length and contained 800 seeds. The sainfoin selections and the 2 sweetclover selections failed to become established and thus were eliminated from the June field tests. However, one sweetclover selection, (Mal 47) did become established later and was tested in place of crown vetch during the August test. Malathion at the rate of $1 / 2 \mathrm{lb}$ active ingredient/acre was sprayed on the plots and border areas before field tests were initiated in order to control grasshoppers hatching within the plots. Tests with caged grasshoppers were conducted twice during the summer; in June with nymphs of $M$. sanguinipes, $M$. bivittatus, and Ageneotettix deorum and in August with adults of $M$. packardii and a mixed population of nymphs and adults were $M$. femurrubrum made up 75\% of the population. Field cages were constructed of aluminum screen and measured $50 \times 50 \times 50 \mathrm{~cm}$. Seedlings of most plants averaged $3-6 \mathrm{~cm}$ in height when the June test was completed and $10-20 \mathrm{~cm}$ when the August test was completed.

Three 24-hour tests were carried out in June. Each test consisted of 40 cages ( 4 cages/plant selection):

Test 1 -cages were infested with 30 (4 5 instar) $M$. sanguinipes;

Test 2-same as test 1 except nymphs of $A$. deorum were used;

Test 3-cages were infested with 12 (4-5 instar) $M$. bivittatus. Seedling counts were made before and after grasshopper feeding. Grasshoppers had the opportunity to feed either on the legume test plant or on $B$. inermis or $A$. desertorum which was growing on either side of the furrow that contained the legume. Grasshoppers were removed from all cages at the end of the 24-hour test period.

Two tests were carried out in August. Each test consisted of $\mathbf{4 0}$ cages (4 cages/plant selection):

Test 1 -each cage was infested with 20 adult $M$. packardii for a period of $\mathbf{4 0}$ hours. The number of plants and their average height was recorded before and after feeding.

Test 2-each cage was infested with a mixture of species consisting of both nymphs and adults. About $75 \%$ of the mixture was $M$. femurrubrum.

Selections with more than average foliage were infested at the rate of 80 grasshoppers/cage: Mandan composite-1, Mal 40, Ladak 65, Orenburg, Mal 47, and Mandan Composite-2. The selections which had less foliage were infested at the rate of 40 grasshoppers /cage: Mal 20, ML 1974, Cree, and Mal 28. Grasshoppers were removed from the cages after 46 hours. The number of plants and 
Table 2. Averase time spent feeding by 5 adult grasshoppers of each of 4 Melanoplus species on 15 plant selections during a 30-min. period, Bozeman, Mont. 1980.

\begin{tabular}{|c|c|c|c|c|c|c|}
\hline \multirow{3}{*}{$\frac{\text { Plant selection }}{\text { Sainfoin-Eski }}$} & \multicolumn{6}{|c|}{ Avg feeding time (sec) } \\
\hline & glad & $\begin{array}{l}M . \\
\text { Istoni }\end{array}$ & $\begin{array}{c}M . \\
\text { femultubrum }\end{array}$ & \multirow{2}{*}{$\begin{array}{r}\begin{array}{r}M . \\
\text { pacardii }\end{array} \\
437^{2}\end{array}$} & \multicolumn{2}{|c|}{$\begin{array}{c}M . \\
\text { sanguinipes }\end{array}$} \\
\hline & 920 & a & $436^{2}$ & & 444 & bcd 1 \\
\hline Alfalfa-Ladak 65 & 905 & $\mathbf{a}$ & 536 & 255 & 223 & de \\
\hline Sweetclover-ML 2177 & 866 & ab & 412 & 334 & 456 & bcd \\
\hline Sainfoin-Melrose & 860 & $\mathbf{a b}$ & 436 & 317 & 535 & b \\
\hline Sainfoin-Remont & 854 & $\mathbf{a b}$ & 387 & 453 & 435 & bcd \\
\hline Sweetclover-Mal 47 & 818 & $\mathbf{a b c}$ & 494 & 469 & 482 & bc \\
\hline Alfalfa-Mal $\mathbf{4 0}$ & 797 & $a b c$ & 416 & 182 & 451 & bc \\
\hline Trefoil-Mal 20 & 697 & abcd & 272 & 349 & 139 & e \\
\hline Crown vetch-ML 1978 & 686 & abcd & 382 & 248 & 361 & bede \\
\hline Alfalfa-Orenburg & 602 & abcd & 563 & 243 & 235 & de \\
\hline Trefoil-ML 1974 & 535 & bed & 347 & 258 & 234 & de \\
\hline \multicolumn{7}{|l|}{ Cicer milkvetch- } \\
\hline Mandan Composite-2 & 519 & bed & 291 & 169 & 353 & bcde \\
\hline Hairy vetch-Mal 28 & 478 & cd & 319 & 501 & 919 a & $\mathbf{a}$ \\
\hline Trefoil-Cree & 461 & cd & 416 & 263 & 245 & cde \\
\hline \multicolumn{7}{|l|}{ Alfalfa-Mandan } \\
\hline Composite-1 & 403 & $d$ & 266 & 280 & 219 & de \\
\hline
\end{tabular}

'Means within each column followed by the same letter are not significantly different at the .05 level.

${ }^{2}$ No significant difference at the .05 level.

the total number of leaves on the plants in each cage was recorded before and after feeding. The grasshoppers were closely observed while they were feeding in the cages and the length of the feeding period was determined when a gradient of damage could be observed. Thus tests 1 and 2 lasted for different periods of time.

\section{Results}

Grasshopper development is greatly influenced by the rearing temperature and available food plants. Rearing temperatures in the 90's plus a mixed diet usually speedup development and result in heavier grasshoppers. In contrast, lower rearing temperatures (70's) and unfavorable food plants slow down development and produce smaller grasshoppers. Our results showed that in general, survival was less and the time to reach the adult stage was greater for both $M$. gladstoni and $M$. sanguinipes when reared on the alfalfas, the trefoils, and cicer milkvetch than when reared on the other plant selections, Table 1 . The average dry weight of adults of $M$. gladstoni was also the lowest when reared on the above 3 groups of plants. However, $M$. sanguinipes did not survive on some of the plant selections and thus weight comparisons between grasshoppers reared on the different plants cannot be made. Grasshoppers, in search of food, bite plants in a non-specific manner until a preferred food plant is found after which continued feeding (usually 5-10 minutes) follows. Thus less time would be spent feeding on an unpreferred food plant. In this test the time spent feeding on the different plant selections by 4 grasshopper species was statistically analyzed as shown in Table 2 , but only the tests with $M$. gladstoni and $M$. sanguinipes showed significant differences at the 5\% level. Spearman's coefficient of rank correlation (Steel and Torrie 1960) was used to compare rankings between species to determine if any of the 4 species had similar preferences for the test plants. Only the correlation of $M$. gladstoni and $M$. femurrubrum was significant at the 5\% level indicating that these 2 species fed nearly equally on the test plants.

Although each grasshopper-plant selection interaction probably should be considered individually, in general the grasshoppers fed less on: alfalfa (Mandan composite- 1 and Orenburg); bird sfoot trefoil (Cree and Malzo); and cicer milkvetch (Mandan composite2). It is obvious that the grasshoppers tested preferred the sainfoin and sweetclover selections.

The field tests, in general, confirmed the labortory tests. The average plant mortality and leaf reduction are shown in Table 3. Plant mortality appears to be a valid method for evaluating plant preference at the seedling stage but this method becomes less reliable as the plants get older. For example, hairy vetch was readily fed on (484 leaves destroyed replicate) but the stems were tough and grasshoppers left them standing. Statistical tests showed that data on plant mortality resulting from the feeding of $M$. sanguinipes, $M$. bivittatus, and $M$. packardii were significantly different at the .05 level. However, the tests with $A$. deorum and the mixed populations were not significant at the .05 level. Valid statistical comparisons could not be made with the tests of mixed species since 2 grasshopper densities were used in the test. $A$. deorum is not a forb feeder (Mulkern et al. 1964) but was included in the tests to see how it would compare to other grasshoppers that are recognized pests of forbs. Although leaf reduction did not differ significantly, the 6 plant selections (Mandan composite-1, Orenburg, Mandan composite-2, Cree, Mal 20, Mal 47) least

Table 3. Plant mortality and leaf reduction resulting from the feeding of 4 grasshopper species and 1 mixed population in field cages at Manda, N. Dak. 1980.1

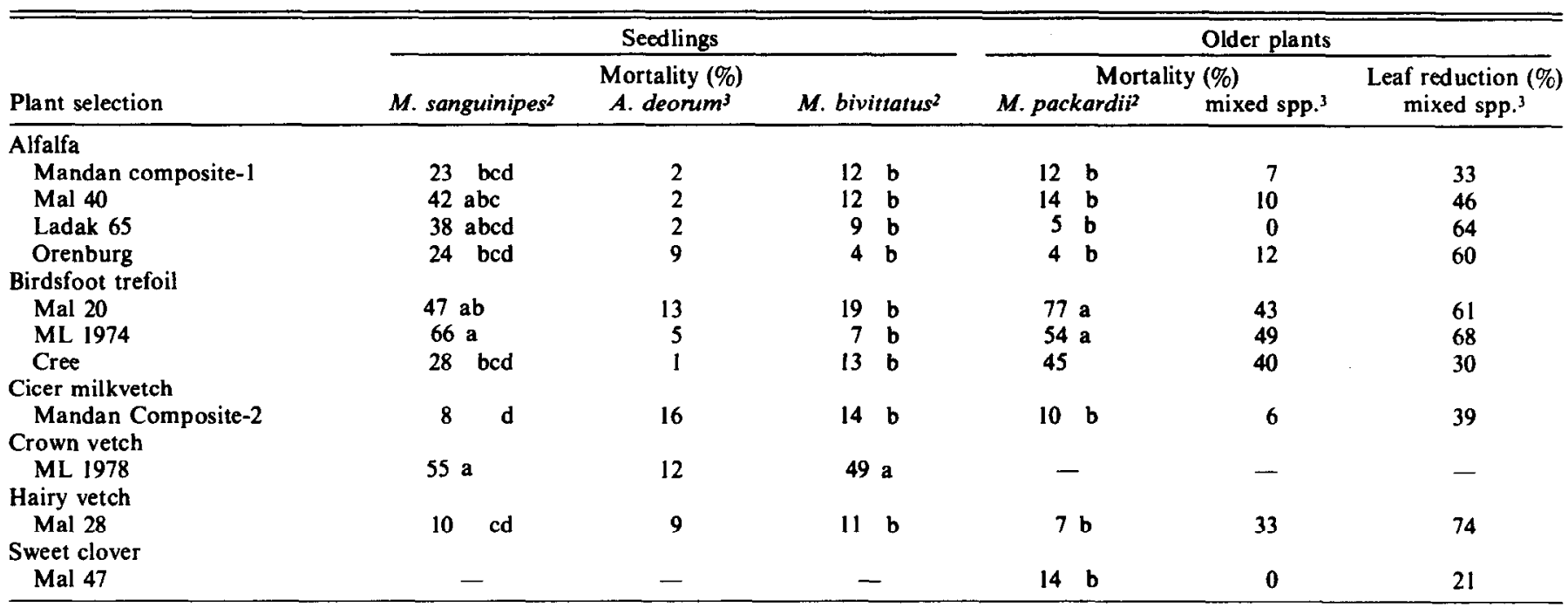

'Tests with seedlings carried out in June, 1980, with nymphs and tests with older plants in August 1980 with adults.

${ }^{2}$ Means within each column followed by the same letter are not significantly different at the .05 level.

${ }^{3}$ No significant difference at the .05 level. 
preferred in the laboratory tests also were fed on the least in the field tests except there was little difference in leaf reduction between the trefoils ML 1974 and Cree. Two other legumes, cicer milkvetch and birdsfoot trefoil (Tana), were cited by Hewitt (1969) as being unpreferred by $M$. sanguinipes on the basis of survival and weight gained as a result of feeding on the plants.

\section{Discussion}

Selections of alfalfa, cicer milkvetch, and birdsfoot trefoil have the greatest potential as candidates for rangeland seeding from the standpoint of showing low preference by grasshoppers during establishment. Of these three species alfalfa appears to have the greatest potential. Alfalfa has been reported as unsuitable as a food plant when fed alone to several species of grasshoppers (Melanoplus), (Brett 1947; Barnes 1955, 1963; Baily and Mukerji 1976). Working in Arizona, Barnes (1959) noted that grasshopper populations were higher in weedy alfalfa fields than in clean fields. This was also confirmed by Mulkern et al. (1962). Thus a mixed diet, which would be promoted by seeding legumes into rangeland, is best for growth and population buildup of grasshopper species that prefer forbs. It is unlikely that any legume species will have total resistance to grasshopper feeding. However, results of our tests show that grasshoppers are selective in choosing food plants and some plants are definitely less preferred than others. Thus additional studies involving the selection of plants that are least preferred by grasshoppers are indeed justified. Since grasshoppers feeding on rangeland have a choice of food plants, low or nonpreference would be the main resistance factor; however, plant tolerance might also be important. Future attempts at screening plants with grasshoppers should concentrate on nonpreference with the hope that some plant selections will receive less feeding by grasshoppers of the genus Melanoplus.

\section{Literature Cited}

Atkins, M.D. 1962. Conservation plant materials for the Great Plains. J. Soil and Water Conserv. 17:199-203.

Baily, C.G., and M.K. Mukerji. 1976. Consumption and utilization of various host plants by Melanoplus bivittatus (Say) and M. femurrubrum (DeGeer) (Orthoptera:Acrididae). Can. J. Zool. 54:1044-1050.

Bames, O.L. 1955. Effect of food plants on the lesser migratory grasshopper. J. Econ. Entomol. 48:119-124.

Barnes, O.L. 1959. Effect of cultural practices on grasshopper populations in alfalfa and cotton. J. Econ Entomol. 52:336-337.

Bames, O.L. 1963. Food-plant tests with the differential grasshopper. J. Econ. Entomol. 56:396-399.

Bleak, A.T., N.C. Frishchknecht, A.P. Plummer, and R.E. Eckert, Jr. 1965. Problems in artificial and natural revegetation of the arid shadescale vegetation zone of Utah and Nevada. J. Range Manage. 18:59-65.

Brett, C.H. 1947. Interrelated effects of food, temperature, and humidity on the development of the lesser migratory grasshopper (Melanoplus mexicanus mexicanus (Saussare) (Orthoptera). Oklahoma Agr. Exp. Sta. Tech. Bull. T-26, 50 p.

Brown, E.M. 1956. Seeding ladino in grass sods. Crops and Soils. 9:10-11. Cooper, C.S., A.E. Carleton, and F.R. Eslick. 1971. Birdsfoot trefoil in Montana. Montana Agr. Exp. Sta. Bull. 652, 14 p.

Cooper, C.S. 1977. Growth of the legume seedling. Adv. Agron. 29:119. 139.
Craig, C.H. 1978. Damage potential of the sweetclover weevil, Sitona cylindricollis (Coleoptera: Curculionidae), in the Canadian prairies. Can. Entomol. 110:883-889.

Gomm, F.B. 1964. Comparison of two sweetclover strains and Ladak alfalfa alone and in mixtures with crested wheatgrass for range and dryland seedings. J. Range Manage. 17:19-23.

Heinrichs, D.H. 1963. Creeping alfalfas. Adv. in Agron. 15:317-337.

Heinrichs, D.H. 1971 a. Drylander alfalfa. Can. J. Plant Sci. 51:430-432.

Heinrichs, D.H. 1971 b. Spreading rate of creeping-rooted alfalfa. Can. J. Plant Sci. 51:367-370.

Henson, P.R., and H.A. Schoth. 1962. The trefoils-Adaptation and culture. USDA Agr. Handbook 223, 16 p.

Hewitt, G.B. 1969. Twenty-six varieties of forage crops evaluated for resistance to feeding by Melanoplus sanguinipes. Ann. Entomol. Soc. 62:737-741.

Hewitt, G.B., and W.H. Burleson. 1976. A preliminary survey of the arthropod fauna of sainfoin in central Montana. Montana Agr. Exp. Sta. Bull. 693, 11 p.

Johnston, A., S. Smoliak, R. Hironaka, and M.R. Hanna. 1971. Oxley cicer milkvetch. Can. J. Plant Sci. 51:428-429.

Johnston, A., S. Smoliak, M.R. Hanna, and R. Hironaka. 1975. Cicer milkvetch for western Canada. Can. Dep. Agr. Publ. 1536, 16 p.

Kilcher, M.R., and D.H. Heinrichs. 1966. Persistence of alfalfas in mixture with grasses in a semiarid region. Can. J. Plant Sci. 46:163-167.

Kilcher, M.R., and D.H. Heinrichs. 1968. Rates of seeding rambler alfalfa with dryland pasture grasses. J. Range Manage. 21:248-249.

Kneebone, W.R. 1959. Evaluation of legumes for western Oklahoma rangelands. Okla. Agr. Exp. Bull. B539, 13 p.

Lorenz, R.J., R.E. Ries, C.S. Cooper, C.E. Townsend, and M.D. Rumbaugh. 1982. Alfalfa for dryland grazing. USDA, Agr. Info. Bull. No. 444, $24 \mathrm{p}$.

Mulkern, G.B., J.F. Anderson, and M.A. Brusven. 1962. Biology and ecology of North Dakota grasshoppers. 1. Food habits and preferences of grasshoppers associated with alfalfa fields. N. Dakota Agr. Exp. Sta. Res. Rep. No. 7, 26 p.

Mulkern, G.B., D.R. Toczek, and M.A. Brusven. 1964. Biology and ecology of North Dakota grasshoppers. N. Dakota Agr. Exp. Sta. Res. Rep. No. $11,59 \mathrm{p}$.

Rauzi, F., A. Herold, and L. Landers. 1974. Annual and perennial legume establishment trials in eastern Wyoming. Wyo. Agr. Exp. Sta. Res. J. 78, 7 p.

Rumbaugh, M.D. 1965. Initial stands of interseeded alfalfa. J. Range Manage. 18:258-261.

Rumbaugh, M.D., G. Semeniuk, R. Moore, and J.D. Colburn. 1965. Travois an alfalfa for grazing. S. Dakota Agr. Exp. Sta. Bull. 525, 8 p.

Rumbaugh, M.D., and M.W. Pedersen. 1979. Survival of alfalfa in five semiarid range seedings. J. Range Manage. 32:48-51.

Seaney, R.R., and P.R. Henson. 1970. Birdsfoot trefoil. Adv. Agron. 22:119-157.

Smoliak, S., A. Johnston, and M.R. Hanna. 1972. Germination and seedling growth of alfalfa, sainfoin, and cicer milkvetch. Can. J. Plant Sci. 52:757-762.

Steel, R.G.D., and J.H. Torrie. 1960. Principles and procedures of statistics. Mc Graw-Hill Book Co., Inc. New York, N.Y. 481 p.

Stroh, J.R., A.E. Carleton, and W.J. Seamards. 1972. Management of Lutana cicer milkvetch for hay, pasture, seed, and conservation uses. Montana Agr. Exp. Sta. Bull. 666. 17 p.

Townsend, C.E., G.O. Hinze, W.D. Ackerman, and E.E. Remmenga. 1975. Evaluation of forage legumes for rangelands of the central Great Plains. Colorado Agr. Exp. Sta. Gen. Ser. 942, 10 p.

Vogel, W.G., and .W.A. Berg. 1968. Grasses and legumes for cover on acid stripmine spoils. J. Soil and Water Conserv. 23:89-91.

Wilton, A.C., R.E. Ries, and L. Hofmann. 1978. The use and improvement of legumes for ranges. N. Dakota Farm Res. 36:29-31. 